\title{
Pulmonary abnormalities on high-resolution computed tomography in patients with long standing rheumatoid arthritis
}

\author{
Iulia Andronache ${ }^{1,2}$, Cristina Suta ${ }^{3,4}$, Sabina Ciocode ${ }^{3,4}$, Ionut Bulbuc ${ }^{5,6}$, ClaudiaMihailov ${ }^{3,7}$, \\ Oana Arghir ${ }^{8,9}$, Maria Suta ${ }^{1,3}$ \\ ${ }^{1}$ Doctoral School of Medicine, "Ovidius" University, Constanta, Romania \\ ${ }^{2}$ Rheumatology Department, Internal Medicine Clinic, "Dr. Alexandru Gafencu“ Emergency Military Hospital, Constanta, \\ Romania \\ ${ }^{3}$ 3rd Department, Ist Clinical Medical Disciplines, Faculty of Medicine, "Ovidius" University, Constanta, Romania \\ ${ }^{4}$ Rheumatology Department, 2nd Internal Medicine Clinic, "Sf. Apostol Andrei" Emergency Clinical County Hospital, \\ Constanta, Romania \\ ${ }^{5}$ Medimar Imagistic Services, Constanta, Romania \\ ${ }^{6} 1$ st Department, Preclinical Disciplines, Faculty of Medicine, "Ovidius" University, Constanta, Romania \\ ${ }^{7}$ Rheumatology Department, 2nd Internal Medicine Clinic, CF Clinical Hospital Constanta, Romania \\ 8 4th Department, IInd Clinical Medical Disciplines, Faculty of Medicine, "Ovidius" University, Constanta, Romania \\ ${ }^{9}$ Clinical Pneumophtisiology Hospital, Constanta, Romania
}

\begin{abstract}
Background. Rheumatoid arthritis (RA) is a systemic inflammatory disease, associated with a number of extra-articular organ manifestations. Pulmonary involvement is a frequent and severe extraarticular manifestations of rheumatoid arthritis. RA can affect lung parenchyma, airways and pleura.

Objectives. To identify RA-related lung disease on chest computed tomography (CT).

Material and methods. We performed high-resolution computed tomography (HRCT) on a total of 92 patients with longstanding RA.

Results. The subjects were predominantely female (79.3\%), the age at entry was $63.77 \pm 11.56$ years, and $42.9 \%$ had a history of smoking. Disease duration was $15.00 \pm 11.55$ years. Pulmonary CT abnormalities were found in 71 of the 92 patients (77.2\%). The most common HRCT anomalies were: linear attenuation (reticulation) $(52.11 \%)$, bronchiectasis andbronchial wall thickening $(45 \%)$, nodular attenuation $(39.43 \%)$ and pleural involvement (pleural effusion or thickening) (39.43\%).

Conclusions. We conclude that RA-related lung disease was commonly detected on chest CT imaging in longstanding RA patients.
\end{abstract}

Keywords: rheumatoid arthritis, interstitial lung disease, imaging

\section{INTRODUCTION}

Rheumatoid arthritis (RA) is a systemic inflammatory disease. Its main feature is persistent, symmetrical, erosive synovitis, but a large number of extraarticular manifestations can occur in virtually any organ leading to cutaneous, ocular, hematological, cardiovascular and pulmonary lesions (1).
Pulmonary involvement occurs in $60-80 \%$ of patients with RA and can affect any component of the lung. The spectrum of rheumatoid arthritis-associated respiratory disease includes a wide range of pulmonary abnormalities: interstitial lung disease (ILD), airway disease (AD), nodules, pleural disease and vascular disease (2-4).

\section{Corresponding authors:}

Cristina Suta

E-mail: cris_duminica@yahoo.com

Oana Arghir

E-mail: arghir_oana@yahoo.com 
Prevalence rates of pulmonary abnormalities in RA reported in the literature vary widely, depending on the criteria used to define disease, methods used to detect pulmonary involvementand patient populations examined. It has been reported that RA-associated lung disease is seen more frequently in men with longstanding rheumatoid disease, in the presence of high rheumatoid factor titers and in the setting of more severe joint involvement. However, it is a subject of debate. High resolution computed tomography (HRCT) has been proven to be useful for the detection and characterization of morphological changes in the lungs of RA patients (1).

\section{OBJECTIVE}

Our aim was to investigate the prevalence and types of pulmonary involvement in patients with longstanding rheumatoid arthritis using high-resolution computed tomography scan (HRCT).

\section{MATERIAL AND METHODS}

Our study included 92 RA patients. They were diagnosed according to the ACR/EULAR 2010 criteria. All patients were recruited from "Sf. Apostol Andrei" Emergency Clinica County Hospital of Constanța from June 2017 to June 2019. Data collected were: patients' characteristics, including age, sex and smoking history, history regarding respiratory symptoms (cough, dyspnea, sputum production), serum levels of anti-citrullinated protein antibody and rheumatoid factor (RF), disease activity as assessed by the Disease Activity Score-28/Erythrocyte sedimentation rate (DAS28-ESR), medication for RA(diseasemodif yingantirheumaticdrugs). All patients underwent plain radiograph chest $\mathrm{P} / \mathrm{A}$ and chest HRCT. HRCT images were evaluated independently by a radiologist, rheumatologist and a pulmonologist. HRCT abnormalities included the following findings: (1) bronchial dilatation (bronchiectasis), (2) bronchial wall thickening, (3) airspace consolidation, (4) nodular attenuation (including parenchymal micronodules, nodules and subpleural micronodules), (5) ground-glass attenuation, (6) linear attenuation (reticulation), (7) honeycombing, (8) architectural distortion, (9) emphysematous lesions, (10) enlarged lymph nod, (11) pleural abnormalities (pleural thickening, pleural calcification, pleural effusion) (5-7).

Pulmonary abnormalities described above were classified into four main domains: interstitial lung disease (ILD) (ground-glass opacity, reticular pattern, honeycombing, consolidation), airway disease
(AD) (bronchiolitis, bronchial wall thickening, bronchiectasis, cystic bronchiectasis), nodular lesions (including parenchymal micronodules, nodules, and subpleural micronodules) and others (pleural thickening, pleural calcification, pleural effusion, lymph node enlargement, emphysematous lesions -low attenuation area/LAA- and atelectasis $(5,6,8)$.

Tuberculosis (TB) sequelae, definedas apical nodules associated with fibrotic changes, were excluded.

Statistical analysis was performed using SPSS 20.0 software. Numerical variables, analysed using Student $t$ test, were expressed as mean \pm SD. Categorical variables, evaluated using Chi-square test or exact Fisher test, were expressed as frequencies and percentages.

\section{RESULTS}

\section{Study cohort characteristics}

The subjects were predominantely female, 73 $(79.3 \%)$, the mean age at entry was $63.77 \pm 11.56$ years and 39 patients $(42.9 \%)$ had a history of smoking, with a mean of $18.19 \pm 17.26$ pack-years. Mean age at RA onset was $50.7 \pm 15.25$ years and disease duration was $15.00 \pm 11.55$ years. All patients had long standing disease. Anti-CCP antibody and RF were positive in $81.5 \%$ and $90.2 \%$ of the subjects, respectively. Metothrexate was the cDMARD used in 50 of our subjects $(53.8 \%)$. Erosive disease was identified in 70 subjects (76.1\%). Most patients were overweight or obese and mean BMI was of $29.53 \pm 28.07$. Respiratory symptoms were present in 65 patients $(70.7 \%)$, with exertional dyspnea being the main complaint in 59 of the cases $(64.1 \%)$, followed by non productive cough in 46 patients $(50 \%)$ and productive cough in 15 cases $(16.3 \%)$. The X-ray abnormalities were present in 46 of cases $(50 \%)$ and 71 patients $(77.2 \%)$ had abnormal chest $\mathrm{CTs}$ (Table 1).

Pulmonary CT anomalies were correlated with respiratory symptoms and chest X-ray changes. There were no significant correlations between the presence of HRCT pulmonary lesions and the patients' demographic characteristics (age, sex, smoking history) or the RA features (disease duration, RF seropositivity, disease activity, the severity of joint involvement, methotrexate therapy) (Table 2).

The most prevalent chest HRCT abnormalities are identified in the pulmonary parenchyma, linear attenuation, groundglass opacity, airspace consolidation, honeycombing and archytectural dystortion being the structural anomalies characteristic of interstitial lung disease (ILD) (9) (Table 3, Table 4). 
TABLE 1. Study cohort characteristics

\begin{tabular}{|c|c|c|}
\hline Variable $(n=92)$ & Patients (\%) & $\begin{array}{c}\text { Mean and standard } \\
\text { deviation }\end{array}$ \\
\hline Women & $73(79.3 \%)$ & \\
\hline Age & - & $63.77 \pm 11.56$ years \\
\hline BMI $\left(\mathrm{kg} / \mathrm{m}^{2}\right)$ & & $27,19 \pm 5.17$ \\
\hline $\begin{array}{l}\text { History of } \\
\text { smoking }\end{array}$ & $39(42.9 \%)$ & \\
\hline Disease duration & - & $15.00 \pm 11.55$ years \\
\hline Positive RF & $83(90.2 \%)$ & \\
\hline $\begin{array}{l}\text { Anti CCP } \\
\text { antibodies }\end{array}$ & 75 (81.5\%) & \\
\hline $\begin{array}{l}\text { Active disease } \\
\text { (DAS28-ESR) } \\
\end{array}$ & 69 (75.1\%) & \\
\hline MTX & $50(53.8 \%)$ & \\
\hline TB sequelae & $14(15.2 \%)$ & \\
\hline $\begin{array}{l}\text { Respiratory } \\
\text { symptoms }\end{array}$ & $65(70.7 \%)$ & \\
\hline $\begin{array}{l}\text { X-ray pulmonary } \\
\text { anomalies }\end{array}$ & $46(50 \%)$ & \\
\hline $\begin{array}{l}\text { Chest HRCT } \\
\text { anomalies }\end{array}$ & $71(77.2 \%)$ & \\
\hline
\end{tabular}

TABLE 2. Main features of the patients presenting with CT changes.

\begin{tabular}{|l|c|c|c|}
\hline & $\mathbf{C T}(\mathbf{+})(\mathbf{n}=\mathbf{7 1})$ & $\mathbf{C T}(-)(\mathbf{n}=\mathbf{2 1})$ & $\mathbf{P}$ \\
\hline Women & $55(77.5 \%)$ & $18(85.7 \%)$ & 0.547 \\
\hline $\begin{array}{l}\text { Smoking } \\
\text { history }\end{array}$ & $64 \pm 11.43$ & $63 \pm 12.24$ & 0.73 \\
\hline $\begin{array}{l}\text { Disease } \\
\text { duration }\end{array}$ & $13.8 \pm 9.88$ & $19.00 \pm 15.59$ & 0.071 \\
\hline Positive RF & $65(91.7 \%)$ & $18(85.7 \%)$ & 0.42 \\
\hline $\begin{array}{l}\text { Active disease } \\
\text { (moderate/ } \\
\text { high disease } \\
\text { activity) }\end{array}$ & $44(62 \%)$ & $12(57.1 \%)$ & 0.69 \\
\hline Erosions & $54(76.1 \%)$ & $16(76.2 \%)$ & 0.9 \\
\hline Methotrexate & $40(56.3 \%)$ & $10(47.6 \%)$ & 0.481 \\
\hline $\begin{array}{l}\text { Respiratory } \\
\text { symptoms }\end{array}$ & $59(83.1 \%)$ & $6(28.6 \%)$ & $<0.001$ \\
\hline $\begin{array}{l}\text { Chest Xray } \\
\text { abnormalityes }\end{array}$ & $44(62.0 \%)$ & $2(9.5 \%)$ & $<0.001$ \\
\hline
\end{tabular}

They are seconded by the CT abnormalities suggestive for airway disease (AD) (bronchial dilatation and bronchial wall thickening). Pleural changes were identified in 28 patients (39.43\%): 21 cases had pleural thickening, 2 patients had an isolated pleural effusion and in 5 cases these changes coexisted. Positive high-resolution computed tomography findings are presented in the table below (Table 3).
TABLE 3. Main pulmonary lesion types among patients

\begin{tabular}{|l|c|}
\hline Lesion type (\%) & $\mathbf{N}=\mathbf{7 1}$ \\
\hline $\begin{array}{l}\text { Linear attenuation } \\
\text { (reticulation) }\end{array}$ & $52 \%$ \\
\hline Nodular attenuation & $39.43 \%$ \\
\hline $\begin{array}{l}\text { Bronchial dilatation } \\
\text { (bronchiectasis) }\end{array}$ & $33.8 \%$ \\
\hline Bronchial wall thickening & $11.26 \%$ \\
\hline Pleural abnormalities & $39.43 \%$ \\
\hline Enlarged lymph nodes & $29.57 \%$ \\
\hline Emphyzema & $28.16 \%$ \\
\hline Ground-glass attenuation & $9.85 \%$ \\
\hline Airspace consolidation & $8.45 \%$ \\
\hline Honeycombing & $7.04 \%$ \\
\hline Archytectural distortion & $5.63 \%$ \\
\hline Air trapping & - \\
\hline
\end{tabular}

TABLE 4. Main causes of pulmonary lesions $(N=71)$

\begin{tabular}{|c|c|c|}
\hline \multirow{5}{*}{ ILD } & Groundglass opacity & $9.85 \%$ \\
\hline & Reticular pattern & $52 \%$ \\
\hline & Honeycombing & $7.04 \%$ \\
\hline & Consolidation & $8.45 \%$ \\
\hline & $\begin{array}{c}\text { Archytectural } \\
\text { dystortion }\end{array}$ & $5.63 \%$ \\
\hline \multirow{2}{*}{$\begin{array}{l}\text { AIRWAY } \\
\text { DISEASE }\end{array}$} & Bronchiectasia & $33.8 \%$ \\
\hline & $\begin{array}{c}\text { Bronchial wall } \\
\text { thickening }\end{array}$ & $11.26 \%$ \\
\hline NODULAR LESION & Nodular pattern & $39.43 \%$ \\
\hline \multirow{4}{*}{ OTHER } & Pleural thickening & $36.6 \%$ \\
\hline & Pleural effusion & $9.8 \%$ \\
\hline & $\begin{array}{c}\text { Emphysematous } \\
\text { lesions }\end{array}$ & 28.16 \\
\hline & $\begin{array}{l}\text { Enlarged lymph } \\
\text { node }\end{array}$ & $29.57 \%$ \\
\hline
\end{tabular}

\section{DISCUSSIONS}

Even though cardiovascular disease is the most common cause of RA-related death, pulmonary manifestations contribute significantly to morbidity, leading to a mortality of $10-20 \%$ in RA patients (3).

Our study showed that RA patients had considerable changes on chest HRCT, with higher or similar rates when compared to other studies investigating pulmonary HRCT features in patients with longstanding RA (Table 5) $(2,8,10-12)$. 
TABLE 5. Clinical and demographic features of RA patients with CT abnormalities

\begin{tabular}{|l|c|c|c|c|c|c|}
\hline & Remy-Jardin, 1994 & Cortet, 1997 & Youssef, 2012 & Shawky, 2020 & Tanaka, 2020 & $\begin{array}{c}\text { Andronache, } \\
\mathbf{2 0 2 1}\end{array}$ \\
\hline $\begin{array}{l}\text { Patients who } \\
\text { underwent chest } \\
\text { HRCT }\end{array}$ & 77 & 68 & 36 & 82 & 208 \\
\hline Age (years) & $57 \pm 9$ & $58.8 \pm 10.6$ & 48,5 (median) & $59.43 \pm 3.68$ & $59.25 \pm 13.16$ & $63.77 \pm 11.56$ \\
\hline $\begin{array}{l}\text { Disease dura-tion } \\
\text { (years) }\end{array}$ & $12 \pm 8$ & $12 \pm 9.2$ & 8 (median) & $6.01 \pm 2.02$ & $7.94 \pm 9.31$ & $15.00 \pm 11.55$ \\
\hline FR (+) & $\mathrm{NA}$ & $52(76.5 \%)$ & $28(77.8 \%)$ & $64(78.8 \%)$ & $175(84.1 \%)$ & $83(90.2 \%)$ \\
\hline Smoking his-tory & $8(10.38 \%)$ & $16(23.5 \%)$ & none & $16(19.5 \%)$ & $97(46.8 \%)$ & $39(42.9 \%)$ \\
\hline $\begin{array}{l}\text { Respiratory } \\
\text { symptoms }\end{array}$ & $27(35.06 \%)$ & - & NA & $35(42.7 \%)$ & $21(10.1 \%)$ & 65 (70.7\%) \\
\hline CT findings & $\begin{array}{l}38 \\
(49 \%)\end{array}$ & $55(80.9 \%)$ & $17(47.2 \%)$ & $47(57.3 \%)$ & $146(70.2 \%)$ & $71(77.2 \%)$ \\
\hline
\end{tabular}

TABLE 6. Chest CT anomalies in RA patients

\begin{tabular}{|c|c|c|c|c|c|c|c|c|}
\hline Lesion type (\%) & $\begin{array}{c}\text { Remy-Jardinet } \\
1994 \\
(n=77)\end{array}$ & $\begin{array}{l}\text { Cortet } 1997 \\
\quad(n=68)\end{array}$ & $\begin{array}{c}\text { Tanaka } \\
2004 \\
\text { (n=63 }\end{array}$ & $\begin{array}{c}\text { Mori } 2008 \\
(n=61)\end{array}$ & $\begin{array}{l}\text { Youssef } \\
2012 \\
(n=36)\end{array}$ & $\begin{array}{c}\text { Shawky } 2020 \\
\quad(n=82)\end{array}$ & $\begin{array}{c}\text { Tanaka } \\
2020 \\
\text { (n=146) }\end{array}$ & $\begin{array}{c}\text { Andronache } \\
2021 \\
(n=71)\end{array}$ \\
\hline $\begin{array}{l}\text { Bronchial } \\
\text { dilatation } \\
\text { (bronchiectasis) }\end{array}$ & \multirow[t]{2}{*}{$30 \%$} & \multirow[t]{2}{*}{$30.5 \%$} & \multirow[t]{2}{*}{$75 \%$} & $49.2 \%$ & \multirow[t]{2}{*}{$36.1 \%$} & $12.2 \%$ & \multirow[t]{2}{*}{$41.3 \%$} & $33.8 \%$ \\
\hline $\begin{array}{l}\text { Bronchial wall } \\
\text { thickening }\end{array}$ & & & & $18 \%$ & & $17.1 \%$ & & $11.26 \%$ \\
\hline $\begin{array}{l}\text { Nodular } \\
\text { attenuation }\end{array}$ & $22 \%$ & $28 \%$ & $49 \%$ & $47.5 \%$ & $11.1 \%$ & $29.2 \%$ & $21,6 \%$ & $39.43 \%$ \\
\hline $\begin{array}{l}\text { Linear } \\
\text { attenuation } \\
\text { (reticulation) }\end{array}$ & $18 \%$ & - & $98 \%$ & $13.1 \%$ & $22.2 \%$ & - & $20.2 \%$ & $52 \%$ \\
\hline $\begin{array}{l}\text { Ground-glass } \\
\text { attenuation }\end{array}$ & $14 \%$ & $17.1 \%$ & $90 \%$ & $26.2 \%$ & $11.1 \%$ & $24.2 \%$ & $6.3 \%$ & $9.85 \%$ \\
\hline Honeycombing & $10 \%$ & $2.9 \%$ & $60 \%$ & $9.8 \%$ & $5.6 \%$ & $12.2 \%$ & $6.7 \%$ & $7.04 \%$ \\
\hline $\begin{array}{l}\text { Airspace } \\
\text { consolidation }\end{array}$ & $6 \%$ & - & $35 \%$ & $4.9 \%$ & - & $8.5 \%$ & $7.7 \%$ & $8.45 \%$ \\
\hline $\begin{array}{l}\text { Archytectural } \\
\text { dystortion }\end{array}$ & $6 \%$ & - & $62 \%$ & 0 & - & - & - & $5.63 \%$ \\
\hline Emphyzema & $5 \%$ & & $24 \%$ & - & $5.6 \%$ & - & - & $28.16 \%$ \\
\hline Air trapping & - & $25 \%$ & $43 \%$ & - & - & - & - & - \\
\hline $\begin{array}{l}\text { Enlarged lymph } \\
\text { node }\end{array}$ & $9 \%$ & - & $20 \%$ & - & - & - & - & $29.57 \%$ \\
\hline $\begin{array}{l}\text { Pleural } \\
\text { abnormalities }\end{array}$ & $16 \%$ & $1.5 \%$ & $29 \%$ & - & $5.6 \%$ & - & - & $39.43 \%$ \\
\hline
\end{tabular}

The prevalence and type of pulmonary abnormalities identified on chest HRCT vary among different studies and reasons for that are: different definitions, aims and heterogeneous patient populations (Table 6) (1,2,6,8,10-12). Lack of a unitary classification leads to dissipated data. However, the lesions suggestive for airway disease (bronchial dilatation and bronchial wall thickening) are constantly present in at least $30 \%$ of the cases (30$75 \%$ ). In our study, linear attenuation (reticulation), as asign of ILD, is the most frequent $\mathrm{CT}$ finding $(52 \%)$. 
The Remy-Jardinet et al. 1994 cohort included 84 patients $(65.47 \%$ women), with a mean disease duration of $12 \pm 8$ years). Thirty eight (49\%) patients had abnormal CT scans. Abnormalities identified were: bronchiectasis $(30 \%)$, pulmonary nodules $(22 \%)$, ground glass attenuation (14\%) and honeycombing $(10 \%)(10)$.

In 1997, Cortet et al. compared the results of pulmonary function tests (PFTs) and lung HRCT in rheumatoid arthritis (RA) patients. This study included 68 patients, $(79.41 \%$ women) with a mean age of 58.8 years (range: $35-82$ ) and a mean disease duration of 12 years (range: 5-16). Rheumatoid factor was positive in 52 patients $(76.5 \%)$. Fifty two patients $(76.5 \%)$ were lifelong non-smokers. Fifty-five patients displayed an abnormal HRCT pattern. The most frequent HRCT findings were: bronchiectasis $(30.5 \%)$, pulmonary nodules $(28 \%)$, and air trapping (25\%). Ground glass attenuation and honeycombing were present in $17.1 \%$, respectively $2.9 \%$ of the patients(2).

Akira et al. studied 29 RA patients (22 of them $75.86 \%$ with CT changes) and they identified three major patterns on $\mathrm{CT}$ : reticulation with or without honey combing $(86.36 \%)$, centrilobular branching lines with or without bronchial dilatation $(22.72 \%)$ and consolidation (22.72\%) (13).

The advent of lung HRCT lead to the possibility of a more detailed assessment of lung involvement: Youssef et al., in 2012, in a series comprising nonsmokers, 34 females (94.4\%) and 2 males (5.6\%), with median age of 48.5 years and median disease duration of 8 years, $77.8 \%$ positive for RF, and nearly two-thirds (28/36) of the patients with one or more pulmonary symptom such as dyspnea, cough, wheezing or phlegm, yielded the following results: based on the HRCT findings, abnormalities were detected in 17 patients $(47.2 \%)$. In regards to the type of pulmonary involvement detected, interstitial lung disease was the commonest as it was detected in 14 patients $(38.9 \%)$. Eight patients $(22.2 \%)$ had reticular opacities, while two $(5.6 \%)$ had honeycombing and 4

Conflict of interest: none declared

Financial support: none declared

\section{REFERENCES}

1. Mori S, Cho I, Koga Y, Sugimoto M. Comparison of pulmonary abnormalities on high-resolution computed tomography in patients with early versus longstanding rheumatoid arthritis. J Rheumatol. 2008 Aug;35(8):1513-21.

2. Cortet B, Perez T, Roux N, Flipo RM, Duquesnoy B, Delcambre $B$, Rémy-Jardin M. Pulmonary function tests and high resolution computed tomography of the lungs in patients with rheumatoid arthritis. Ann Rheum Dis. 1997 Oct;56(10):596-600.
(11.1\%) had ground-glass opacity. Bronchial abnormalities were detected in 13 patients $(36.1 \%)$, emphysema in $2(5.6 \%)$, rheumatoid pulmonary nodules in 4 patients $(11.1 \%)$, and pleural effusion in $2(5.6 \%)$ (11).

Sabri et al., in 2015, evaluated HRCT findings in patients with pulmonary complications of RA. The study involved 20 patients, $70 \%$ women, aged 16-64 years (average 48 years). All patients were known cases of RA presenting with dyspnea and cough. All of them had HRCT changes: 9 cases (45\%) showed signs of interstitial disease (bilateral sub-pleural predominantly basal ground glass opacification, bilateral sub-pleural predominantly basal reticulation with traction bronchiolectasis, diffuse ground glass), 9 cases $(45 \%)$ airway disease (hyperinflation, bronchial wall thickening, mild bronchiectasis , mosaic perfusion, beading of the bronchial wall - suggesting follicular bronchiolitis) and findings of both entities in 2 cases (10\%) (14).

Recently, in 2020, Shawky et al. presented data from their cohort: eighty-two longstanding RA patients (the mean duration was $72.15 \pm 24.03$ months), 57 females and 25 males, mean age $59.43 \pm 3.68$ years, 16 smokers (19.5\%), 35 patients complaining of respiratory symptoms (42.7\%); abnormal CT findings were detected in 47 patients (57.3\%): ground glass appearance in $24,4 \%$, bronchial wall thickening in $17.1 \%$, micronodules in $29.2 \%$ (parenchymal $14.6 \%$ and subpleural $14.6 \%$ ), honeycomb appearance in $12.2 \%$, bronchial dilatation in $12.2 \%$. (12).

\section{CONCLUSIONS}

Pulmonary involvement evaluated via chest HRCT is present in a high percentage of RA patients, even in those with no chest X-ray findings or respiratory complaints. We identified interstitial lung disease as the main cause of pulmonary lesions, followed by airway disease. While there is a high proportion of pleural abnormalities, some may be secondary to previous TB infection.
3. Amital A, Shitrit D, Adir Y. The lung in rheumatoid arthritis. Presse Med. 2011 Jan;40(1 Pt 2):e31-48.

4. Sidhu HS, Bhatnagar G, Bhogal P, Riordan R. Imaging features of the pleuropulmonary manifestations of rheumatoid arthritis: pearls and pitfalls. J Clin Imaging Sci. 2011;1:32.

5. Yamagata M, Ikeda K, Tsushima K, lesato K, Abe M, Ito T, Kashiwakuma D, Kagami S, Iwamoto I, Nakagomi D, Sugiyama T, Maruyama Y, Furuta S, Jayne D, Uno T, Tatsumi K, Nakajima H. 
Prevalence and Responsiveness to Treatment of Lung Abnormalities on Chest Computed Tomography in Patients With Microscopic Polyangiitis: A Multicenter, Longitudinal, Retrospective Study of One Hundred Fifty Consecutive Hospital-Based Japanese Patients. Arthritis Rheumatol. 2016 Mar;68(3):713-23.

6. Tanaka N, Kim JS, Newell JD, et al. Rheumatoid arthritis-related lung diseases: CT findings. Radiology. 2004 Jul;232(1):81-91.

7. Hansell, DM, Bankier, AA, MacMahon, et al. Fleischner Society: glossary of terms for thoracic imaging. Radiology 2008;246: 697-722.

8. Tanaka A, Kurasawa K, Soda S et al Developmental pathways of pulmonary abnormalities in rheumatoid arthritis according to sequential HRCT findings. Research Square 2020 (preprint).

9. Chansakul T, Dellaripa PF, Doyle TJ, et al. Intra-thoracic rheumatoid arthritis: Imaging spectrum of typical findings and treatment related complications. Eur J Radiol. 2015 Oct;84(10):1981-91.

10. Remy-Jardin M, Remy J, Cortet B, Mauri F, Delcambre B. Lung changes in rheumatoid arthritis: CT findings. Radiology. 1994 Nov;193(2):375-82.
11. Youssef AA, Machaly SA, El-Dosoky ME, El-Maghraby NM. Respiratory symptoms in rheumatoid arthritis: relation to pulmonary abnormalities detected by high-resolution CT and pulmonary functional testing. Rheumatol Int. 2012 Jul;32(7):1985-95.

12. Shawky R, Alzokm SM, Al-Deek A. Pulmonary abnormalities, clinically, functionally, and radiologically in patients with rheumatoid arthritis: correlation with duration and disease activity. The Egyptian Journal of Chest Diseases and Tuberculosis. 2020;69(1):197-206.

13. Akira M, Sakatani M, Hara H. Thin-section CT findings in rheumatoid arthritis-associated lung disease: CT patterns and their courses. J Comput Assist Tomogr. 1999 Nov-Dec;23(6):941-8.

14. Sabri YY, Taymour TA, Shaban MM, et al. The role of HRCT in evaluation of thoracic manifestations of rheumatoid arthritis. Egyptian Journal of Chest Diseases and Tuberculosis. 2016;65(1):319-23. 